\title{
Comparative Analysis of Atmospheric Carbon Dioxide Concentration and Temperature between Forest and Non-Forested Domains in Oyo State, Nigeria
}

\section{*AWOSUSI, BM; ADAMU, IS; ORUNKOYI, AR; ATIBA, DO; OBE, AA; AMORI, MD; ADEDOYIN, ED}

\author{
Environmental Modeling and Biometrics Department, Forestry Research Institute of Nigeria, P.M.B. 5054, Jericho, Ibadan, Oyo State, \\ Nigeria \\ *Corresponding Author Email: monisola.bola@yahoo.com; Tel: +2348067331666
}

\begin{abstract}
This study was carried out to assess the concentration levels of $\mathrm{CO}_{2}$ and temperature and also to correlate their values among selected locations in Oyo State, Nigeria. $\mathrm{CO}_{2}$ and temperature readings were taken using a portable $\mathrm{CO}_{2}$ meter, and a GPS was use to capture co-ordinates of sample points, this was done twice a day. Data were collected from $7 \mathrm{am}$ to $11 \mathrm{am}$ for morning session while afternoon session data were collected between $1 \mathrm{pm}$ and $5 \mathrm{pm}$ making a total of 8 hours monitoring. There were negative correlation between $\mathrm{CO}_{2}$ and temperature in all the forests while we have positive correlation between $\mathrm{CO}_{2}$ and temperature in non-forested domains, this, by implication, means that presence of trees in the forest reserve help to reduce Carbon dioxide during the day since trees manufacture their food using $\mathrm{CO}_{2}$ in the presence of sunlight. Also, the positive correlation between $\mathrm{CO}_{2}$ and temperature in the towns is due to high rate of human anthropogenic activities during the day. The values of $\mathrm{CO}_{2}$ obtained in this study were higher when compared with IPCC limit of $435 \mathrm{ppm}$ (parts per million) of $\mathrm{CO}_{2}$ emission. Routine monitoring of carbon dioxide and public education is recommended.
\end{abstract}

DOI: https://dx.doi.org/10.4314/jasem.v25i3.21

Copyright: Copyright (c) 2021 Awosusi et al. This is an open access article distributed under the Creative Commons Attribution License (CCL), which permits unrestricted use, distribution, and reproduction in any medium, provided the original work is properly cited.

Dates: Received: 12 December 2020; Revised: 26 January 2021; Accepted: 12 February 2021

Keywords: Carbon dioxide, Temperature, Forest, Non-Forest, Forest Reserve

A proper understanding of the relationship between the concentration of atmospheric $\mathrm{CO}_{2}$ and global temperature is a prerequisite to evaluating anthropogenic impact on climate change (Davis, 2017). $\mathrm{CO}_{2}$ concentration is increasing slowly but continuously with a typical seasonal fluctuation mostly due to the burning of the fossil fuels for energy needs (Tomomi, et al., 2012). Carbon dioxide concentrations are rising mostly because of the fossil fuels that people are burning for energy. Fossil fuels like coal and oil contain carbon that plants pulled out of the atmosphere through photosynthesis over the span of many millions of years; we are returning that carbon to the atmosphere by felling of trees. Anthropogenic activities have been found to contribute more than $80 \%$ of the atmospheric $\mathrm{CO}_{2}$ in non-forested domains (Koerner and Klopatek, 2002). The interaction between $\mathrm{CO}_{2}$ and temperature will certainty exert a profound influence on the earth's environment and global agricultural production (Rosenzweig et al., 2014). Growing evidence suggest how global background levels of atmospheric $\mathrm{CO}_{2}$ are increasing and his impact on environmental quality, human and ecological health (Ana et.al, 2015). Scientists measure the amount of greenhouse gases in the atmosphere in several ways. They use satellites and other instruments such as sensors to measure the amount of greenhouse gases in the air all around the world. Greenhouse gas such as $\mathrm{CO}_{2}$ trap heat just like the glass roof of a greenhouse, helps warming the globe. The rise in $\mathrm{CO}_{2}$ level has been observed to be more rapid than at any time in the past due to increase in anthropogenic activities. Carbon IV oxide $\left(\mathrm{CO}_{2}\right)$ emissions arising from human anthropogenic activities predisposes to adverse health outcomes and associated health risks, this may include headaches, dizziness, restlessness, difficulty breathing, sweating, tiredness, increased heart rate etc. We must reduce emissions of greenhouse gases to net zero to have a reasonable chance of limiting global warming to $1.5^{\circ} \mathrm{C}$ to prevent global disaster. The main objective of this paper is to evaluate the atmospheric carbon dioxide concentration and temperatures between forest and non-forested domains in Oyo State, Nigeria

\section{MATERIALS AND METHODS}

Study Area: Oyo state is an inland state in the south western part of Nigeria, with its capital in Ibadan. It is bounded in the North by Kwara State, East by Osun State, South by Ogun State and in West partly by 
Ogun State and partly by the republic of Benin. Oyo state is located on the map on $7^{0} 22^{\prime} 43^{\prime \prime} \mathrm{N}, 7^{0}$ $3784^{\prime \prime} \mathrm{N}$ and $3^{\circ} 53^{\prime} 43^{\prime \prime}$ E, $3^{\circ} 89^{\prime} 53^{\prime \prime}$ E Oyo State covers an area of 28,245.3 square kilometers. It has a population of 5,580,894 (2006 census figures).The average annual temperature is $25.9^{\circ} \mathrm{C}$.

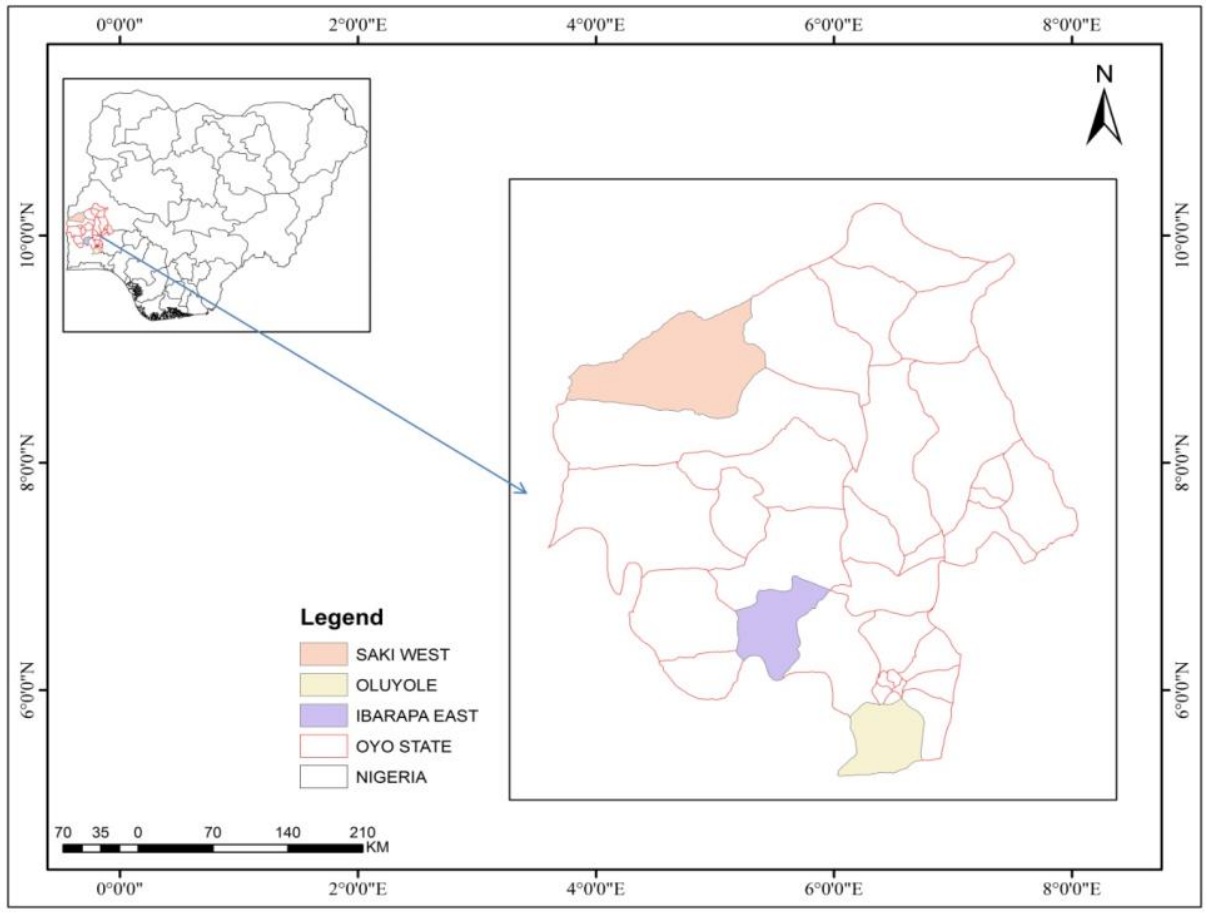

Fig 1: Map of the Study Area

Table 1: Study Locations

\begin{tabular}{lll}
\hline Number & Non-Forested Domain & Forest Domain \\
\hline 1 & Saki Town & Wasangare Forest Reserve \\
2 & Eruwa Town & Eruwa Forest Reserve \\
3 & Idi Ayunre & Gambari Forest Reserve \\
\hline
\end{tabular}

Data Collection: Three Forests domain (Wasangare, Eruwa and Gambari) and Non-Forested domain (Saki town, Eruwa town and Idi Ayunre town) close to each Forest reserve (Table 1) were purposively selected for this study. A Garmin Geo-Positioning System device was used to navigate through the coordinates of the laid sampling points while a hand-held neutron air quality meter-AQ-9901SD was used for measuring and storing the atmospheric $\mathrm{CO}_{2}$ and temperature of the study points, taking the emitting zones into consideration during the measurements.

\begin{tabular}{lll}
\multicolumn{2}{c}{ Table 2: Possible emitter of carbon dioxide in the study area } \\
\hline S/N & Location & Observable sources \\
1 & Idi Ayunre Town & Generators, Residential, Industries, Gas station \\
2 & Gambari Forest Reserve & Dead wood, soil and dead leaves \\
3 & Saki Town & Automobile, Generator, Residential, Industries, Gas station \\
4 & Wasangare Forest Reserve & Dead wood, soil and dead leaves \\
5 & Eruwa Town & People, Automobiles, Gas station and school environment \\
6 & Eruwa Forest Reserve & Dead wood, soil and dead leaves, charcoal production site \\
\hline
\end{tabular}

Data Exploration and Analysis: Data exploration, summary and analysis was carried out using $\mathrm{R}$ version 4.0.3 ( $\mathrm{R}$ Core Team, 2020) while graphics were produced using ggplot2 (Wickham, 2016)-a package in $\mathrm{R}$. Tools used for data summarization are tables and bar charts.
Pearson's correlation coefficient: was used to measure the relationship between the variables considered for this study $\left(\mathrm{CO}_{2}\right.$ and temperature). It has a value between -1 and +1 and is of the form: 


$$
\boldsymbol{r}=\frac{\sum_{i=1}^{n}\left(X_{i}-\bar{X}\right)\left(Y_{i}-\bar{Y}\right)}{\sqrt{\sum_{i=\mathbf{1}}^{n}\left(X_{i}-\bar{X}\right)^{2} \sum_{i=1}^{n}\left(Y_{i}-\bar{Y}\right)^{2}}}
$$

Where: $\mathrm{r}=$ correlation coefficient; $X_{i}=$ values of the $\mathrm{x}$-variable in a sample; $\bar{X}=$ Mean of the values of the $\mathrm{x}$-variable; $Y_{i}=$ values of the $\mathrm{y}$-variable in a sample; $\bar{Y}=$ Mean of the values of the $\mathrm{y}-$ variable

Welch's t-test: was used to determine the similarity of measurements obtained on each variable in the forested area to the corresponding variable measured at the community close to the forest area. The Welch's $\mathrm{t}$-test is given as:

With

$$
\boldsymbol{t}=\frac{\left(\bar{X}_{1}-\bar{X}_{2}\right)-\left(\mu_{1}-\mu_{2}\right)}{\sqrt{\frac{S^{2}}{n_{1}}+\frac{S^{2}}{n_{2}}}}
$$

$$
d f=\frac{\frac{\sigma_{1}}{n_{1}}+\frac{\sigma_{2}}{n_{2}}}{\frac{\left(\frac{\sigma_{1}}{n_{1}}\right)^{2}}{n_{1}-1}+\frac{\left(\frac{\sigma_{2}}{n_{2}}\right)^{2}}{n_{2}-1}}
$$

Where $t$ connotes Welch's t-statistic and df represents the degree of freedom for the Welch's test.

\section{RESULT AND DISCUSSION}

Descriptive analysis: A summary of the observations on carbon (IV) oxide and temperature at the study locations are presented on Table 3.

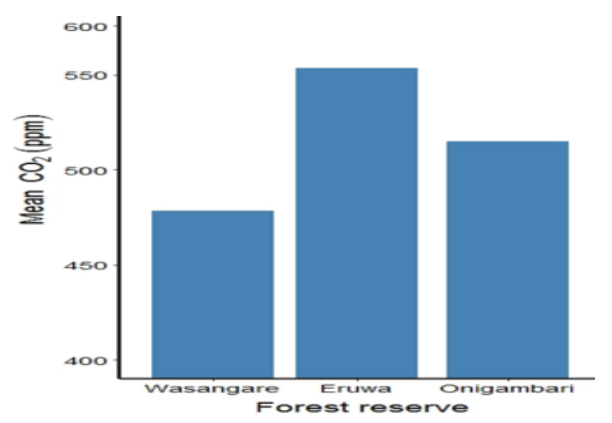

Fig 2: Mean $\mathrm{CO}_{2}$ concentrations for the forest reserves

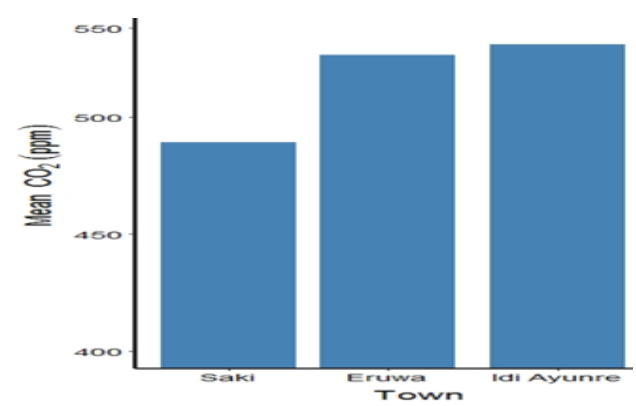

Fig 3: Mean $\mathrm{CO}_{2}$ concentration for Non-forested domain

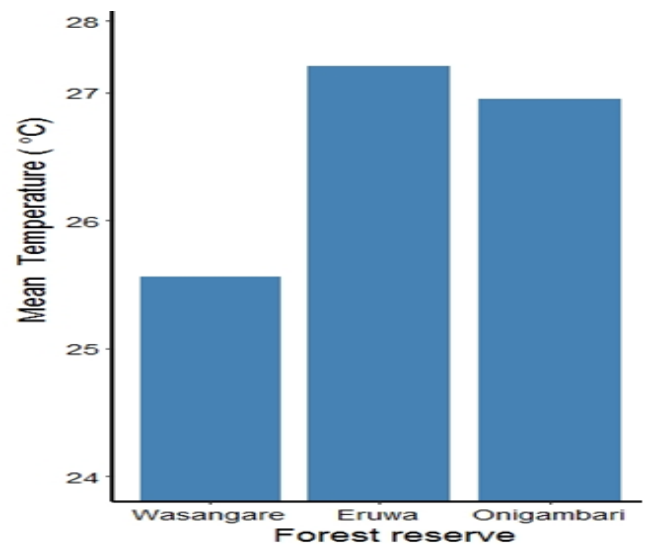

Fig 4: Mean Temperature for selected forest reserves
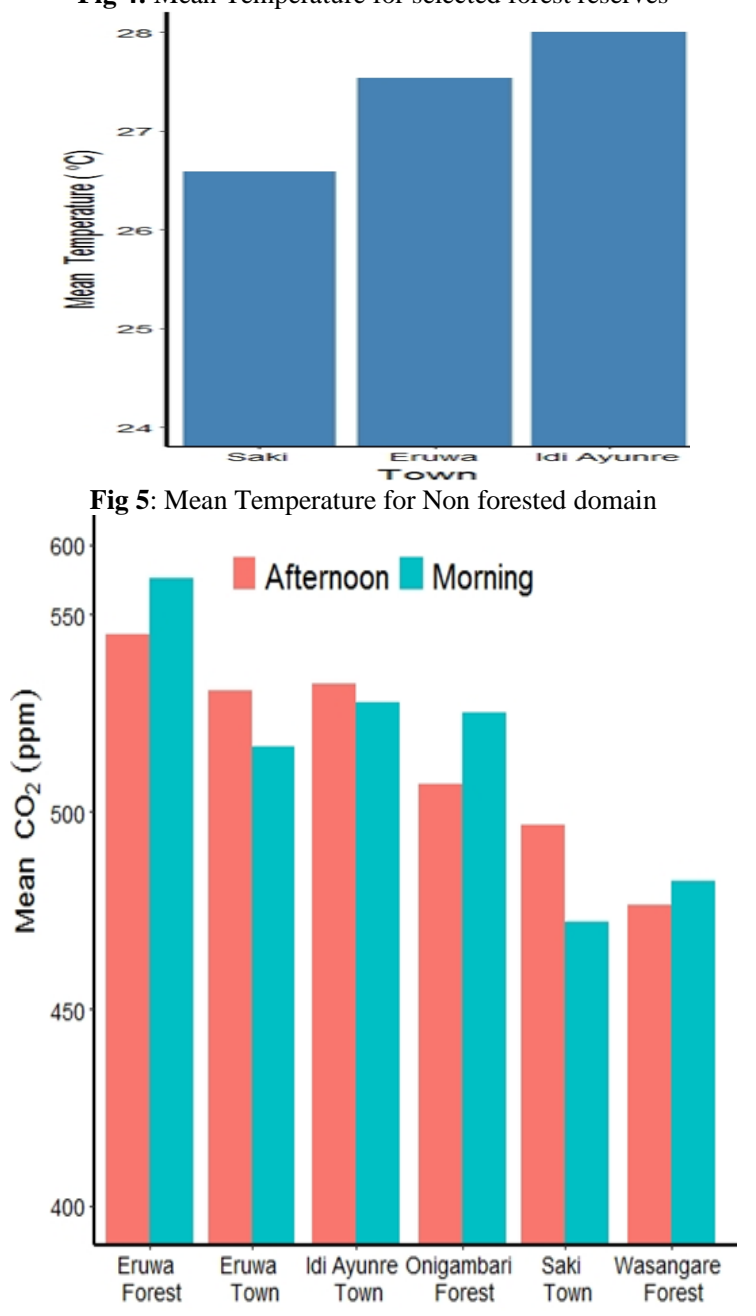

Fig 6: Mean $\mathrm{CO}_{2}$ for Morning and Afternoon periods

The highest average $\mathrm{CO}_{2}$ concentration was recorded at Eruwa Forest reserve while the lowest average concentration occurred at Wasangare Forest Reserve. Incidentally, the lowest mean temperature was measured at Wasangare Forest Reserve while the highest mean temperature was observed at Eruwa Forest Reserve (Table 3). 


\begin{tabular}{|c|c|c|c|c|c|}
\hline $\begin{array}{l}\text { Location } \\
\text { (Forest } \\
\text { Domain) }\end{array}$ & $\begin{array}{l}\text { Mean } \\
\mathrm{CO}_{2} \\
(\mathrm{ppm})\end{array}$ & $\begin{array}{l}\text { Mean } \\
\text { Temperature } \\
\left({ }^{\circ} \mathrm{C}\right)\end{array}$ & $\begin{array}{l}\text { Non- } \\
\text { Forested } \\
\text { Domain }\end{array}$ & $\begin{array}{l}\text { Mean } \\
\mathrm{CO}_{2} \\
(\mathrm{ppm})\end{array}$ & $\begin{array}{l}\text { Mean } \\
\text { Temp. } \\
\left({ }^{\circ} \mathrm{C}\right)\end{array}$ \\
\hline Wasangare & 478.48 & 25.52 & Saki & 489.18 & 26.59 \\
\hline Eruwa Forest & 553.41 & 27.21 & Eruwa Town & 526.47 & 27.54 \\
\hline Onigambari & 514.95 & 26.95 & Idi Ayunre & 531.09 & 28.00 \\
\hline
\end{tabular}

\begin{tabular}{lll}
\multicolumn{3}{c}{ Table 4: Correlation between $\mathrm{CO}_{2}$ and Temperature } \\
\hline Location & $\mathrm{r}$ & Remark \\
\hline Saki Town & 0.5119 & Positively correlated \\
Wasangare Forest Reserve & -0.3849 & Negatively correlated \\
Eruwa Town & 0.5910 & Positively correlated \\
Eruwa Forest Reserve & -0.4018 & Negatively correlated \\
Idi Ayunre Town & 0.2236 & Positively correlated \\
Onigambari Forest Reserve & -0.5126 & Negatively correlated \\
\hline
\end{tabular}

Table 5: Welch's t-test for $\mathrm{CO}_{2}$ comparison between the forested and non-forested domain

\begin{tabular}{|c|c|c|c|c|c|}
\hline Non-forested area & Forested area & t-value & df & p-value & Remark \\
\hline Eruwa Town & Eruwa Forest Reserve & -2.8034 & 23.4240 & 0.0042 & Statistically significantly different \\
\hline Saki Town & $\begin{array}{l}\text { Wasangare Forest } \\
\text { Reserve }\end{array}$ & 2.5198 & 75.6920 & 0.0010 & Statistically significantly different \\
\hline Idi Ayunre Town & Gambari Forest Reserve & 3.0327 & 41.4370 & 0.0042 & Statistically significantly different \\
\hline
\end{tabular}

In other words, Eruwa forest had the highest mean $\mathrm{CO}_{2}$ concentration and mean temperature while Wasangare had the lowest mean concentration and mean temperature (Figure 2, Figure 4) amongst the forest reserves. On the other hand, for non-forested areas, Idi Ayunre had the highest mean $\mathrm{CO}_{2}$ concentration and mean temperature while Saki had the lowest mean $\mathrm{CO}_{2}$ concentration and lowest mean temperature (Figure 3, Figure 5). This study further showed a higher mean concentration of $\mathrm{CO}_{2}$ at afternoon period than morning period for the non-forested areas selected in this study while the forest reserves showed a higher concentration of $\mathrm{CO}_{2}$ in the morning periods than afternoon periods (Figure 6).

A Pearson's correlation test between $\mathrm{CO}_{2}$ and temperature observations obtained from the study locations revealed a positive correlation to exist for the variables within the town locations while a negative correlation was observed to exist within each forest reserve. Consequently, the observations showed that an increase in means $\mathrm{CO}_{2}$ characteristically related with an increase in mean temperature for the nonforested domain while an increase in mean $\mathrm{CO}_{2}$ related with a decrease in mean temperature at the forest reserves (Table 4). The disparity in correlation coefficients between $\mathrm{CO}_{2}$ and temperature for the forest and non-forested domain could be attributed to the fact that forests/trees sequester, or make use of carbon (IV) oxide, in the presence of sunlight (that is, increase in temperature), to produce food. Hence, the reduction of $\mathrm{CO}_{2}$ within the forest domains compared to that observed at the non-forested areas. A Welch's $\mathrm{t}$-test showed a marked statistical difference in the measurement of the $\mathrm{CO}_{2}$ concentration for each forest reserve and non-forested domain close to them (Table 5 ), at $95 \%$ confidence interval (i.e. at alpha level equals 0.05 ).

Conclusion: This result shows that the recent $\mathrm{CO}_{2}$ increase is causing the temperature increase in nonforested domain, nonetheless, there exist weak correlations between surface temperature and atmospheric $\mathrm{CO}_{2}$ concentration in the forest. This study reveal that values of $\mathrm{CO}_{2}$ obtained was higher when compared with IPCC limit of $\mathrm{CO}_{2}$ emission which is an average of $435 \mathrm{ppm}$. There is the need for concerted efforts to reduce $\mathrm{CO}_{2}$ in order to stem possible air pollution episodes in the future and this is achievable by routine monitoring of $\mathrm{CO}_{2}$ level and increasing information programs.

Acknowledgement- All thanks to Forestry Research Institute of Nigeria Ibadan, for the support given during this research work.

\section{REFERENCES}

Ana, GR; Ojelabi, P; Shendell, DG (2015). Spatiotemporal variations in carbon dioxide levels in Ibadan, Nigeria. Int. J. Environ. Health. Res. 25(3): 229-240.

Davis, WJ (2017). The Relationship between Atmospheric Carbon Dioxide Concentration and Global Temperature for the Last 425 Million Years. Climate 5: 76. 
Koerner, B; Klopatek, J (2002). Anthropogenic and natural $\mathrm{CO}_{2}$ emission sources in an arid urban environment. Inter. J. Environ. Pollute 116: S45S51.

R Core Team (2020). R: A language and environment for statistical computing. $\mathrm{R}$ foundation for statistical computing, Vienna, Austria. URL: https://www.R-project.org/.

Rosenzweig, C; Elliott, J; Deryng, D; Ruane, AC; Müller, C; Arneth, A; Boote, KJ; Folberth, C; Glotter, M; Khabarov, N; Neumann, K; Piontek, F; Pugh, TA M; Schmid, E; Stehfest, E; Tomomi, Y; Selichiro, Y; Akira, T (2012). Comparison of the Characteristics of small Commercial NDIR $\mathrm{CO}_{2}$ Sensor Models and Development of a portable $\mathrm{CO}_{2}$ measurement device. www.mdpi.com/journal/sensors. ISSN 1424-8220.
Yang, H; Jones, JW (2014). Assessing agricultural risks of climate change in the 21 st century in a global gridded crop model intercomparison. Proc. Natl. Acad. Sci., 111(9): 3268-3273

Wickham, H (2016). ggplot2: Elegant Graphics for Data Analysis. Springer-Verlag New York. ISBN 978-3-319-24277-4, https://ggplot2.tidyverse.org. 